\title{
Smoke and smoked fish production
}

\author{
Katerina Belichovskal, Daniela Belichovska², Zlatko Pejkovski ${ }^{1}$
}

A b s t $r$ a c t: Smoking is a method for preserving fishes that, after previous salting, are processed with organic components obtained from smoke. Smoke contains volatile aromatic substances that give specific features to fish flesh (attractive appearance, colour, flavour and aroma) and have bactericidal effects. Smoked fish is a flavourful and nutritious product, ready for use with or without further cooking or processing. Besides useful compounds, smoke contains harmful substances that have carcinogenic properties. The quality of smoked fish depends on many factors including the species and size of fish, fish diet, condition and treatment before smoking (fresh, frozen), and the methods of salting, heat treatment and smoking. Depending on the temperature of the smoking chamber, smoking can be cold, warm or hot, and depending on the environment in which smoking is conducted, different smoking techniques are employed: smoking with natural smoke, smoking without smoke and mixed smoking. When smoking is with natural smoke, fish is processed in a smoke-air mixture, which is formed during the direct incomplete combustion (pyrolysis) of wood. Smoking without smoke utilises smoke preparations obtained from smoke or its components. Fish smoked with smoke preparations does not contain harmful components, because smoke preparations are previously purified to remove these substances. Liquid smoke (smoke aqueous solution), which is sufficiently studied, available and has minimal potential toxicity, is attracting more attention today.

Keywords: smoke, smoked fish, polycyclic aromatic hydrocarbon, nitrosamine.

\section{Introduction}

Smoking as a method of preserving food with high amounts of added salt has been applied for centuries for domestic needs. As a result of development of analytical techniques, in recent decades, the notion of traditional smoked products has been overturned. Whole groups of carcinogenic polycyclic aromatic hydrocarbons (PAHs), mutagenic nitrosamines and other harmful substances such as methanol and formaldehyde have been detected in smoke and smoked products. This has imposed the need to find environmentally friendly methods to smoke foods based on effectively cleaning the smoke from the harmful substances and using the smoke preparations thereby produced. Also, the harmful role of excess sodium in the body has served as a stimulus for development of technology to produce low salt smoked foods. Investigation of the effects of smoking on colour, flavour and aroma became the basis for the construction of modern smoking devices, by which process control over smoking is possible. Most attention today is focused on liquid smoke (smoke aqueous solution), which is sufficiently studied and available and has minimal potential for toxicity (Мезенова et al., 2001).
Smoked fish is certainly one of the most attractive fish products. This accounts for the fact that nearly $20 \%$ of the total fish supply on the French market is smoked fish. Cold smoked fish is particularly interesting, and which, depending on the fish species and size, the amount of salt and the thermal processing used, can be consumed with or without additional heat treatment (Baltic et al., 2009).

\section{Production of smoke}

Smoke is a source of heat and of the basic components responsible for the effects of smoking on fish. The composition and properties of smoke depend on the type of wood, its chemical composition, physical properties and burning conditions. Wood from deciduous trees, mostly beech, oak, birch (without bark), linden, maple or aspen are used for quality smoke production. These tree woods burn gently and produce aromatic smoke. Coniferous trees are not recommended, because their wood contains significant quantities of resins that give an unpleasant, bitter taste and aroma and a dark colour to the fish. Wood, shavings or sawdust are usually used for burning. Sawdust in

${ }^{1}$ Ss. Cyril and Methodius University in Skopje, Faculty of Agricultural Sciences and Food, 16-ta Makedonska Brigada 3, 1000 Skopje, North Macedonia;

2 Ss. Cyril and Methodius University in Skopje, Institute of Animal Science, Ilinden 92a, 1000 Skopje, North Macedonia.

*Corresponding author: Daniela Belichovska, daniela.belichovska@gmail.com 
the form of granules is commonly used in practice (Быков, 1980; Мезенова et al., 2001). The humidity of wood should not exceed $25 \%$, and that of sawdust should be $40-50 \%$. Large amounts of steam and low molecular weight acids (e.g. formic, propionic) are created in the smoking chamber at higher humidities, which is undesirable (Мезенова et al., 2001). Smoked fish with an unattractive colour and a bitter taste of resin are obtained if the humidity of raw wood smoke is more than $50 \%$. Moreover, the necessary extraction of water from the fish practically does not occur if the humidity of the smoke is $75-80 \%$ (Былков, 1980).

Wood dry matter consists of cellulose, lignin and hemicellulose. Technological smoke is produced at the optimum temperature for combustion of these substances, i.e. $300-400^{\circ} \mathrm{C}$ and when access of oxygen to the pyrolysis zone of the wood is limited. During pyrolysis of wood materials, the following stages are differentiated:

1) intensive evaporation of water at $100-170^{\circ} \mathrm{C}$;

2) thermal decomposition of hemicellulose at $200-260^{\circ} \mathrm{C}$;

$3)$ thermal decomposition of cellulose at $260-310^{\circ} \mathrm{C}$

4) thermal decomposition of lignin at $310-500^{\circ} \mathrm{C}$.

At the beginning of pyrolysis of wood material, undesirable substances, primarily non-aromatic gases and liquids, charcoal and resin, appear in the smoke. Very important substances are formed in the second stage of pyrolysis, when a complex chemical mixture forms consisting of approximately 10,000 solid, liquid and gaseous organic components, of which about 1,000 participate in creating the properties of the smoked fish. These smoke components are deposited onto the surface of the fish. The intensity of precipitation is proportional to the concentration of smoke, the speed of its movement, the degree of its dispersion, and the temperature and humidity of the product to be smoked. In the primary drip-liquid phase, the smoke is precipitated on dry surfaces, and the gaseous phase onto wet surfaces, due to vapour condensation. The components of the smoke penetrate the fish, with the concentration gradient being the driving force of the process (Мезенова et al., 2001).

\section{Composition of smoke}

The chemical composition of smoke and its condensates is not fully elucidated. So far, $300 \mathrm{com}-$ pounds have been identified in smoke, 288 in condensate, and about 68 in smoked foodstuffs. This testifies to the high reactive ability of the basic components of smoke (alcohols, aldehydes, ketones, keto acids, esters) with smoked foods like fish. The most common compounds are phenols, which lead to the formation of all the effects of smoking (Мезенова et al., 2001).

Forty-seven PAHs were identified in smoke, and about 20 PAHs were detected in smoked meat or fish. However, there are about 200 PAHs, some of which have carcinogenic or mutagenic properties. Studies have shown that not all PAHs have carcinogenic or mutagenic properties, but one of the most common cancer-inducing PAHs is 3,4-benzopyrene, which is abundant in smoke (Мезенова et al., 2001). According to other sources, 660 different PAHs have been described so far, and about 100 PAHs and their alkaline derivatives were identified in smoked fish. It has been proven that 15 PAHs had mutagenic and genotoxic effect on somatic cells of experimental animals in in vivo conditions (Stolyhwo and Sikorski, 2005). These genotoxic PAHs can be considered as potentially genotoxic and carcinogenic to humans. It is considered that PAHs with molecular weights below 216 Da have no carcinogenic effect (Sander and Wise, 1997).

PAHs in smoke are formed during wood combustion from practically all organic compounds in conditions of low oxygen supply and temperatures higher than $400^{\circ} \mathrm{C}$. The likelihood of PAH formation is especially high when the temperature reaches more than $1000^{\circ} \mathrm{C}$ (Мезенова et al., 2001). The content of PAH in smoked fish and meats depends on several factors, the most important being the smoking method (artisanal or industrial) and the temperature at which wood pyrolysis takes place. Temperature plays a significant role in PAH formation, since the concentration of PAH increases proportionally as the pyrolysis temperature increases from $400^{\circ} \mathrm{C}$ to $1000^{\circ} \mathrm{C}$. The optimal temperatures for wood pyrolysis, 300 to $600^{\circ} \mathrm{C}$, are also those at which more useful and fewer harmful, especially potentially carcinogenic PAH compounds are created (Vukovic, 1998).

However, the optimal temperature for wood pyrolysis cannot be produced when fish is traditionally smoked, and nor can the smoke be cleaned of carcinogens. Therefore, there is a risk of the occurrence of harmful compounds in higher concentrations in such traditionally smoked fish products. In modern industrial facilities, smoke is produced in a generator that is separated from the fish. In such conditions, the temperature of sawdust combustion, the presence of air (oxygen) and the air circulation can be controlled. Also, the smoke is channelled from the smoke generator to the smoking chamber, when it can be purified using a variety of techniques (Kilibarda et al., 2009). 
Reduction of PAHs in smoked fish and other foods is possible by regulating the process in the smoke generator, maintaining the sawdust temperature at low levels $\left(<400^{\circ} \mathrm{C}\right.$, so the sawdust smoulders), purifying the smoke before it enters the smoking chamber (mechanical filtration, sedimentation or condensation in water or electrostatic filtration) and using smoke preparations previously cleaned of tar and PAH fractions instead of raw wood smoke. To date, utilisation of smoke preparations appears to be the most effective way to limit the occurrence of PAHs in smoked foods like fish (Мезенова et al., 2001).

3,4-Benzopyrene is the best-studied PAH carcinogenic compound in smoke, and it is also the most abundant (it constitutes about $50 \%$ of all the carcinogenic compounds present in smoke). Therefore, the amount of 3,4-benzopyrene is used as an indicator of all $\mathrm{PAH}$ compounds present in smoked foods, and the maximum allowable level is restricted by European Union law in foods of different origins, including smoked meats and foods intended for feeding infants and young children (Anon, 2005). The content of 3,4-benzopyrene in smoked foods ranges from 0 to $500 \mathrm{ppb}$. According to some standards, the maximum content of 3,4-benzopyrene in smoked products should not exceed $1 \mu \mathrm{g} / \mathrm{kg}$ (Mezanova et al., 2001). Certainly the intake of these carcinogenic compounds is a matter of concern in countries and communities in which fish smoking in artisanal conditions is a local tradition (Baltic et al., 2006).

\section{Basic effects of smoking}

The major beneficial effects of fish smoking are the formation of the typical colour, aroma and flavour of smoked fish and the fish preservation effect. Toxic compounds (PAH, methanol, formaldehyde, some phenols and others) have negative effects, because they precipitate onto the fish surface and reduce the nutrient and biological value of the fish. Therefore it is necessary to control the chemical composition of the smoke, the process of cleaning the smoke (if this is used) and the quality of the finished product. Also, the decreased content (10-20\% decrease) of available amino acids in the fish flesh, since some amino acids react with the smoke components, is a negative effect. Despite this causing the reduced nutritional value of fish after smoking, the digestibility of fish is increased by smoking. Therefore, digestibility of the same kind of fish is in the following order: smoked $>$ boiled $>$ raw $>$ dried $>$ salted. This can be explained by secretory gland activation in digestive organs during digestion of smoked fish (Мезенова et al., 2001).

The intensities of colour, aroma and flavour of smoked fish depend largely on the phenol content in the fish flesh. The actual concentration of smoke affects the sensory properties of smoked fish. High density smoke contains large amounts of resinous substances and acids, and so gives the fish a sour-bitter taste. Low density smoke does not form the desirable golden colour, and the odour of smoke in the finished fish is weak (Быков, 1980). The hue and colour of smoked fish depends on the type of wood used to produce the smoke. Beech, maple and linden give golden-yellow hues, acacia produces a lemon shade, oak produces a cinnamon colour, pear a reddish hue and so on. Smoke from pine (soft wood) colours the smoked fish more intensively than smoke from deciduous trees (Мезенова et al., 2001).

Fish dehydrates during smoking, losing weight and changing its structural-mechanical properties. Organic compounds from the smoke that are deposited on the surface of the fish gradually diffuse into the muscle tissue. The diffusion of various smoke compounds into the fish tissue is uneven; some of them penetrate into the fish flesh, but others remain on the skin or muscle surface, forming a golden brown-coloured membrane (Быкков, 1980).

The preservative effect of smoking is due to the antioxidant actions of smoke components (phenols, polycarboxylic acids), bactericidal effects (the combined effect of antiseptic components of smoke, largely some phenols and acids, dehydration, salt, reducing the $\mathrm{pH}$ and high temperature during hot smoking) and antiproteolytic action (slowing down the autolytic processes, due to the effect of smoke on tissue enzymes) (Мезенова et al., 2001). Meat preservation by smoking is based on the action of heat and smoke components on the microorganisms present and changes in the basic components of the fish muscle. In addition, the amount of water in the flesh decreases, and this is reflected in the quality of the finished smoked fish product (Kolodziejska et al., 2002). Numerous smoke components, i.e. organic acids, alcohols, aldehydes, ketones and particularly phenols, have bacteriostatic and/or fungistatic effects on some types of bacteria and/or fungi (Doe et al., 1998; Leroi et al., 1998; Guillén and Errecalde, 2002). The most important cause of smoked fish spoilage is the growth of microorganisms accompanied by build-up of their metabolic products during storage of smoked fish, which lead to undesirable odours and flavours. Deterioration is also a consequence of enzymes that cause autolytic changes in the texture of the smoked fish during storage (Hansen et al., 1996). 


\section{Fish smoking methods}

Depending on the temperature of the smoking chamber, smoking can be cold, warm or hot. In cold smoking, the temperature in the smoking chamber should not exceed $40^{\circ} \mathrm{C}$. Cold smoked fish is a product of the complex action of $\mathrm{NaCl}$, smoke components, dehydration, and proteolytic and lipolytic enzymes (Мезенова et al., 2001). Cold smoked fish has a delicate aroma of smoke, and it has a longer shelf life than hot smoked fish because it contains significantly less water and more salt (Быков, 1980; Витченко et al., 1981).

In warm smoking, the temperature ranges from $40^{\circ} \mathrm{C}$ to $80^{\circ} \mathrm{C}$. Proteins in the fish are partially denatured, and enzymes are completely inactivated (Мезенова et al., 2001).

In hot smoking, the temperature ranges from $80^{\circ} \mathrm{C}$ to $170^{\circ} \mathrm{C}$. Proteins in the fish are completely denatured, and enzymes are inactivated. The product has low salinity and high water content, it is slightly smoked, soft, and juicy, the mild aroma of smoke is noticeable, and it cannot be stored for a long time (Быкков, 1980).

According to Stolyhwo and Sikorski (2005), temperatures during cold smoking are between $12^{\circ} \mathrm{C}$ and $25^{\circ} \mathrm{C}$, in warm smoking are $25^{\circ} \mathrm{C}$ to $45^{\circ} \mathrm{C}$ and in hot smoking are $40^{\circ} \mathrm{C}$ to $100^{\circ} \mathrm{C}$, reaching temperatures up to $80^{\circ} \mathrm{C}$ in depth of the product. Hot smoking can be performed at $60^{\circ} \mathrm{C}$ to $80^{\circ} \mathrm{C}$ and even higher, so heat processing of the fish occurs simultaneously (Vasiliadou et al., 2005; Salán et al., 2006; Duyar et al., 2008).

Depending on the environment where fish smoking is conducted, there are different smoking methods: smoking with smoke, smoking without smoke and mixed smoking. When smoking with smoke, fish is processed in a smoke-air mixture that is formed by the direct combustion of wood. This fish has a unique flavour and aroma due to the rich chemical composition of the smoke. At the same time, harmful substances like PAHs, formaldehyde, methanol and nitrosamines precipitate on the product.

Smokeless smoking is processing the fish with smoke preparations obtained from smoke or with smoke components. Fish treated with smoke preparations do not contain harmful components such as PAHs and nitrosamines, because these preparations are previously purified. Due to the difficulties in obtaining perfect smoke preparations (with no carcinogens) and suitable processing equipment, smokeless smoking is only slowly being accepted for smoked fish production.

In mixed smoking, processing with and without smoke is combined, which simplifies and expedites the process. Smoking without smoke is preferable from an environmental and sanitary-hygiene aspect (Мезенова et al., 2001). Electrostatic smoking results in the smoking duration being 8 to 10 times shorter than that of ordinary smoking (Былков, 1980).

The process of smoked fish production (method of salting, amount of salt, method of smoking) should ensure production of smoked fish that meet the demands of customers and bring economic benefits to the producer (Cardinal et al., 2001; Espe et al., 2001; Røra et al. 2004; Gallart-Jornet et al., 2007). Regardless of the method of smoking to be used, the fish product should be safe for consumption in spite of smoke containing carcinogenic compounds. Chilled smoked fish must be kept in appropriate conditions and its shelf life monitored. Shelf life determination must be accompanied by sensory evaluation and chemical and bacteriological analyses.

\section{Hot smoked fish}

Many commercial fish species are suitable for production of hot smoked fish. Technologically, hot smoking consists of the following operations: receipt of raw material, defrosting, cutting, washing, salting, rinsing, smoking with or without smoke, packaging and storing.

Initially, fish are sorted and defrosted according to weight. Large fish are defrosted in air at $<20^{\circ} \mathrm{C}$ for $20-30 \mathrm{~h}$ depending on the size of the fish. Small and medium-sized fish are defrosted in water at $15^{\circ} \mathrm{C}$ for $1.5-6 \mathrm{~h}$. Defrosting can also be performed in brine $(3-4 \% \mathrm{NaCl})$ at $20-25^{\circ} \mathrm{C}$. Fish weighing up to $1.5 \mathrm{~kg}$ are directed to hot smoking without cutting. Large fish should be cut into pieces and washed in clean running water at $15-20^{\circ} \mathrm{C}$. Fish are salted to a final salt content in the fish meat of $1.8-2.0 \%$ to enhance the flavour of the finished smoked fish. Dry salting and brining are used. In dry salting, fish are placed in a salting tub and dry salt $(\mathrm{NaCl})$ is poured and rubbed over them; salt is poured into the abdominal cavity and gills. Dry salting requires $7-15 \%$ of the fish weight in salt, and it lasts 6-12 h. Brining is conducted using brine (i.e. a saturated solution of $\mathrm{NaCl}$ in water), a brine:fish ratio of $1: 2$, and it lasts 2-6 h. Simultaneous defrosting and salting can also be applied (Быкков, 1980). Salting has a preservative effect and is a critical production stage that contributes to the smoked fish having adequate shelf life, good flavour and being of suitable quality. The preservative effect of salt is based on the fact that it reduces the water activity of the fish flesh, reducing the amount of water available for microorganisms (Baltic and Teodorovic, 1997). Furthermore, the chloride ions are toxic to some microorganisms 
(Goulas and Kontominas, 2005). Excessive salt is removed from the fish after brining by immersing the fish in water, either running water or showering.

Desalted fish are loaded onto trolleys that enter an industrial smoking chamber with parameters that are automatically managed by a microprocessor. The temperature can be adjusted from $10^{\circ} \mathrm{C}$ to $200^{\circ} \mathrm{C}$ and humidity from $10 \%$ to $100 \%$. Industrial chambers can be adjusted to smoking without smoke (i.e. using liquid smoke). In hot smoked fish production, smokeless smoking is very promising. Special smoking chambers disperse liquid smoke into the atmosphere around the fish or disperse the smoke in the form of steam (Мезенова et al., 2001).

The following operations can be differentiated in hot smoking processes: light drying, light steaming and smoking. Light drying is conducted in warm air at $60-80^{\circ} \mathrm{C}$ and $40-60 \%$ humidity for $20-30$ minutes (Мезенова et al., 2001). The purpose of this operation is to dry the fish surface. Dry surfaces better absorb the smoke and prevent the accumulation of soot. The result is a smooth, solid membrane which gives a desirable appearance to the finished smoked fish (Doe et al., 1998). Light steaming is conducted in hot smoke, air or steam at $100-170^{\circ} \mathrm{C}$ for from 40 minutes to 3 hours. Lower temperatures are used for fatty fish. Smoking is the final operation, and it is performed at $100-120^{\circ} \mathrm{C}$ for from 30 minutes to 3 hours. The finished, hot smoked fish is cooled to $8-12^{\circ} \mathrm{C}$, sorted by size and quality and packed. Packaged hot smoked fish is shelf stable for three days at -2 to $2^{\circ} \mathrm{C}$ (Мезенова et al., 2001).

\section{Cold smoked fish}

Cold smoked fish has a unique flavour and aroma and it is frequently consumed without further cooking. It is prepared from fresh, frozen or salted fish. Frozen fish is defrosted in air, by immersion in water or by water spraying using special equipment. Depending on the species and size of the fish, various fish cuts are produced, but small fish are left entire. Some large fish are just eviscerated, while others are eviscerated, deheaded and cut, depending on the purpose of the finished product (Быков, 1980). Recently, there are trends towards maximum possible cutting of all fish species to increase the yield of edible parts, complex utilisation of the fish raw material, shortening the duration of basic operations (salting, smoking) and application of small packages to increase/improve the marketing possibilities (Мезенова et al., 2001).

Fish intended for cold smoking are salted in one of the ways described earlier. Salted fish containing more than $6 \%$ salt are desalted. Desalted or defrosted fish, and also chilled or freshly harvested fish are rinsed in clean water. Fish are then loaded onto trolleys and continue to cold smoking. Cold smoking is performed in different types of smoking plants (chambers, tunnels, towers). Unlike hot smoking, cold smoking gives a partial curing effect to the fish through the anti-oxidative and antimicrobial actions of smoke and water deprivation. Due to the absence of perfect smoke preparations (i.e. in their production) and to technological weaknesses in their application, cold smoking more often includes the traditional steps of slight air drying and smoking with wood smoke.

Slight air drying is necessary to create a desirable colour on the surface of the cold smoked fish. Cold smoking is conducted at $18-24^{\circ} \mathrm{C}$ and $40-60 \%$ humidity. The more fatty the fish, the lower the temperature. Slight air drying depends on the size of the fish and takes $1-12 \mathrm{~h}$; weight loss is $7-20 \%$. Cold smoking is conducted in a smoke-air mixture at $20-30^{\circ} \mathrm{C}$ and $40-60 \%$ humidity. Fatty fish are cold smoked at $20-24^{\circ} \mathrm{C}$ and leaner fish at $26-30^{\circ} \mathrm{C}$, whereby the temperature should be gradually increased to the maximum (Мезенова et al., 2001). According to other recommendations, the temperature maximum can be up to $32^{\circ} \mathrm{C}$ and for fatty fish up to $29^{\circ} \mathrm{C}$, with $\sim 45 \%$ relative air humidity. Drying and smoking last 24-72 h. During this time, drying shrinkage can be up to $30 \%$. In that case, cold smoked fish is shelf stable for a longer duration, has a more gentle smoke aroma, firmer texture, and contains less water and more salt than hot smoked fish (Sosa, 1989). Cold smoked fish should be cooled to $10-12^{\circ} \mathrm{C}$ and then packaged for storage at $8-10^{\circ} \mathrm{C}$. The shelf life duration depends on the type of packaging, the degree of salinity and smoking and storage conditions, and it ranges between 3 days and 3 months (Мезенова et al., 2001).

\section{Warm smoked fish}

The technology for producing warm smoked fish differs from that for producing cold and hot smoked fish. The main differences are temperature, the duration of processing and fish salinity. Application of warm smoking technology to fish is limited and is used primarily for small fish with salt content of $5-8 \%$. Smoking is conducted in two stages: firstly, smoking is at $18-20^{\circ} \mathrm{C}$ for $1.5-2 \mathrm{~h}$ to complete the process of slight drying and secondly, dense smoke is added, the temperature is increased to $80^{\circ} \mathrm{C}$ and the fish is smoked for 6-8 h. Warm smoked fish can be stored for up to 7 days (Быков, 1980). 


\section{Conclusion}

Further research is required on the individual components of smoke, their qualitative and quantitative determination in smoked fish pro- ducts, and on limiting the content of harmful smoke components in finished smoked fish products. To date, smoking fish using smoke preparations is considered to be safer than using wood smoke.

\title{
Dim i proizvodnja dimljene ribe
}

\author{
Katerina Beličovska, Daniela Beličovska, Zlatko Pejkovski
}

A p s trakt: Dimljenje je način očuvanja ribe koja se, nakon prethodnog soljenja, obrađuje organskim komponentama koje se nalaze u dimu tokom nepotpunog sagorevanja (pirolize) drveta. Dim sadrži isparljive aromatske supstance koje daju specifične osobine mesu (atraktivan izgled, boja, ukus, miris) i imaju baktericidno dejstvo. Dimljena riba je ukusan i hranljiv proizvod, spreman za upotrebu bez ili sa dodatnim kuvanjem ili preradom. Osim korisnog, dim sadrži i štetne supstance koje imaju karcinogena svojstva. Kvalitet dimljene ribe zavisi od mnogih faktora kao što su: vrsta ribe, ishrana, stanje i tretman pre dimljenja (sveži, zamrznuti), način soljenja, termička obrada, način dimljenja, itd. U zavisnosti od temperature komore za dimljenje, dimljenje može biti: hladno, toplo $i$ vruće, a u zavisnosti od sredine u kojoj se dimljenje odvija, postoje različiti načini dimljenja: dimljenje prirodnim dimom, dimljenje bez dima i mešano/kombinovano dimljenje. U slučaju dimljenja sa prirodnim dimom, riba se prerađuje u mešavini dima i vazduha, koja se formira tokom direktnog sagorevanja drveta. Dimljenje bez dima je način prerade ribe korišćenjem preparata dima dobijenih dimom ili njegovim komponentama. Ribe dimljene sa preparatima dima ne sadrže štetne sastojke, jer su preparati dima prethodno prečišćeni od ovih supstanci. Tečni dim (vodeni rastvor dima), koji je dovoljno proučen, dostupan i ima minimalnu potencijalnu toksičnost, danas privlači više pažnje.

Ključne reči: dim, proizvodnja, sastav, dimljena riba.

Disclosure statement: No potential conflict of interest was reported by authors.

\section{References}

Anon (2005). Annex I to Regulation (EC) No466/2001, Commission regulation No 208/2005, Official Journal of the European Union L34/3-5.

Baltic, Z. M. \& Teodorovic, V. (1997). Higijena mesa, riba, rakova i skoljki. Udzbenik, Veterinarski fakultet, Beograd.

Baltic, Z. M., Kilibarda, N., Bjelajac, B., Karabasil, N., Teodorovic, V. \& Dimitrijevic, M. (2006). Policiklicna aromaticna hidrokarbonilna jedinjenja u dimljenim proizvodima od mesa. Prvi medjunarodni kongres Ekologija, zdravlje, rad i sport, Banja Luka, tom 2, 274-279.

Baltic Z. M., Kilibarda, N. \& Dimitrijevic, M. (2009). Cinioci od znacaja za odrzivost ribe i odabranih proizvoda od ribe u prometu. Tehnologija Mesa, 50 (1-2), 166-176.

Быков, П. В. (1980). Технология рыбных продуктов. Пищевая промышленность, Москва, 83-109.

Cardinal, M., Knockaert, C., Torrissen, O., Sigurgisladottir, S., Mórkóre, T., Thomassen, M. \& Vallet, J. L. (2001). Relation of smoking parameters to the yield, colour and sensory quality of smoked Atlantic salmon (Salmo salar). Food Research International, 34 (6), 537-550. doi: 10.1016/S0963-9969(01)00069-2

Doe, P. E., Sikorski, Z., Haard, N., Olley, J. \& Sun Pan, B. (1998). Basic Principles. In: P.E. Doe, Fish drying and processing. Production and quality. Lancaster: Tachnomic Publishing Co, 13-46.
Duyar, H.A., Erdem M.E., Samsun S. \& Kalayci F. (2008). The effects of the different woods on hot-smoking vacuum packed Atlantic bonito (Sarda sarda) stored at $4^{\circ} \mathrm{C}$. Journal of Animal and Veterinary Advances, 7 (9), 1117-1122.

Espe, M., Nortvedt, R., Lie, Ø. \& Hafsteinsson, H. (2001). Atlantic salmon (Salmo salar, L.) as raw material for smoking industry. I: effect of different salting methods on the oxidation of lipids. Food Chemistry, 75 (4), 411-416.

Gallart-Jornet, L., Barat, J. M., Rustad, T., Erikson, U., Escriche, I. \& Fito, P. J. (2007). Influence of brine concentration on Atlantic salmon fillet salting. Journal of Food Engineering, 80 (1), 267-275.

Goulas, A. E. \& Kontominas M. (2005). Effect of salting and smoking-method on the keeping quality of chub mackerel (Scomber japonicus): biochemical and sensory attributes. Food Chemistry, 93 (3), 511-520.

Guillén, M. D. \& Errecalde, M. C. (2002). Volatile components of raw and smoked black bream (Brama raii) and rainbow trout (Oncorhynchus mykiss) studied by means of solid phase microextraction and gas chromatography/ mass spectrometry. Journal of the Science of Food and Agriculture, 82, 945-952.

Hansen, L. T., Gill, T., Røntved, S. D. \& Huss, H. H. (1996). Importance of autolysis and microbiological activity on quality of cold-smoked salmon. Food Research International, 29 (2), 181-188. 
Kilibarda, N., Baltic, M., Dimitrijevic, M., Karabasil, N. \& Teodorovic, V. (2009). The smoked fish - producing and quality. $4^{\text {th }}$ International Conference Fishery, 27-29 May 2009, Faculty of Agriculture, Belgrade, Serbia, Conference Proceedings, pp. 296-306.

Kolodziejska, I., Niecikowska, C., Januszewska, E. \& Sikorski, Z. E. (2002). The microbial and sensory quality of mackerel hot smoked in mild conditions. LWT - Food Science and Technology, 35 (1), 87-92.

Leroi, F., Joffraud, J. J., Chevalier, F. \& Cardinal, M. (1998). Study of the microbial ecology of cold-smoked salmon during storage at $8^{\circ} \mathrm{C}$. International Journal of Food Microbiology, 39 (1-2), 111-121.

Мезенова, О.Я., Ким, И.Н. \& Бредихин, С.А. (2001). Производство копченых пищевых продуктов. Колос, Москва.

Røra, A. M. B., Furuhaug, R., Fjæra, S. O. \& Skjervold, P. O. (2004). Salt diffusion in pre-rigor filleted Atlantic salmon.

Salán, E. O., Galvão J. A. \& Oetterer M. (2006). Use of smoking to add value to the salmon trout. Brazilian Archives of Biology and Technology, 49 (1), 57-62.
Sander, L. C. \& Wise, S. A. (1997). Polycyclic aromatic hydrocarbon structure index. NIST Special Publication 922. National Institute of Standards and Technology, Gaithersburg. https://nvlpubs.nist.gov/nistpubs/Legacy/SP/nistspecialpublication922.pdf

Stolyhwo, A. \& Sikorski, Z. E. (2005). Polycyclic aromatic hydrocarbons in smoked fish - a critical review. Food Chemistry, 91, 303-311.

Sosa, B. (1989). Higijena i tehnologija prerade morske ribe. Skolska knjiga, Zagreb.

Vasiliadou, S., Ambrosiadis, I., Vareltzis, K., Fletouris, D. \& Gavriilidou, I. (2005) Effect of smoking on quality parameters of farmed gilthead sea bream (Sparus aurata L.) and sensory attributes of the smoked product. European Food Research and Technology, 221 (3-4), 232-236.

Витченко, Г.А., Копылов, М.Я., Лебедов, М., Слюсаренко, К.Е. \& Опацкя, М.Э. (1981). Рыбопромысловое дело. Легкая и пищевая промышленность, Москва, 194-203.

Vukovic, I. (1998). Osnove tehnologije mesa. Veterinarska komora Srbije, Beograd.

Paper received: 30.01.2019.

Paper corrected: 17.04.2019.

Paper accepted: 07.05.2019. 